\title{
MINIMIZATION OF VIBROACOUSTIC EFFECTS AS A CRITERION FOR OPERATION OF GEAR TRANSMISSIONS IN ACCORDANCE WITH SUSTAINABLE DEVELOPMENT PRINCIPLES
}

\author{
Andrzej N. WIECZOREK \\ Silesian University of Technology \\ Radosław KRUK \\ TU Clausthal
}

\begin{abstract}
:
In correctly functioning maintenance systems it is most important to prevent possible failures. A reduction of the vibroacoustic effects accompanying the operation of machines and equipment, including transmissions, is among the factors that lower the probability of a failure. The paper presents the results of the research on the impact of operational factors on vibroacoustic conditions of transmissions. The factors covered by the analysis included a change in the mating conditions of gear wheels associated with the wear of tooth surfaces, operation of transmissions in subharmonic conditions of the main resonance and the temperature of the lubricating oil. The study demonstrated that it was possible to reduce the vibroacoustic effects generated by gear transmissions by changing the conditions of their operation. Based on the results obtained, it has been found that the operation of gear transmissions in accordance with the sustainable development principles requires technical services to take active measures consisting in the search for optimal operating conditions in terms of the vibroacoustic conditions.
\end{abstract}

Key words: vibrations, noise, design, gearboxes

\section{INTRODUCTION}

This study is a continuation of the paper [1] that presented a concept of designing machines and equipment in accordance with the sustainable development principle. In that paper the attention was drawn to the development of the computer computational and graphical techniques, thanks to which a result that meets the technical criteria assumed could be obtained faster. On the one hand, this may lead to higher demand for natural resources due to the replacement of the existing products with newer solutions, but on the other hand it is easier to find solutions that counteract the degradation of entire technical systems or minimize the impact of their operation on the natural environment. The second approach is consistent [2] with the principles of sustainable development of the industry and services sectors. One of these principles is "creation of goods and services that do not pollute the environment, conserve energy and natural resources, are economically viable, healthful and satisfying for the producer, society and consumers" [3].

The study [1] proposes that one of the criteria for designing in line with the aforementioned concept should be minimization of vibrations and noise generated by machines. The design approach in question was examined on the example of gear transmissions, for which it is very difficult to achieve a reduction in noise and vibrations levels due to their highly advanced technology. However it should be added that in recent years industrial enterprises have paid considerable attention to the issues of maintaining drive units (including gear transmissions) of machines and equipment in a satisfactory technical condition. Such a condition can be achieved primarily through organizational changes and the use of appropriate lubricants, but also through the introduction of technical diagnostics for assessing the condition of the machines. A reduction of the vibrations and noise occurring during the operation of these machines has also a huge impact on people's working conditions and thus on their effectiveness. In recent times, the probability of exceeding the admissible values of the factors in questions keeps increasing due to a substantial increase in the power rating of motors installed in drives of machines and equipment. The mining industry, where the total power rating of drives increased twofold in the last decade, is an explicit example.

This paper describes methods of obtaining knowledge about the dynamics of machines as well as discusses the causes of vibroacoustic effects in mining gear transmissions. It also presents the impact of selected operational factors on the level of vibrations and noise generated by such transmissions.

\section{METHODS OF OBTAINING KNOWLEDGE ABOUT THE VIBROACOUSTIC CONDITIONS OF GEAR TRANSMISSIONS}

As a result of the growing competition between manufacturers, the time required for the design phase of the product manufacturing process is reduced. The product development can be realized by the use of $[4,5,6,7]$ : 
- analytical method for solving mathematical equations that describe a given phenomenon or process,

- experimental method for obtaining knowledge,

- hybrid method combining both methods mentioned above.

Many physical phenomena are described in the form of differential equations resulting from the accepted models describing the phenomena or processes (examples of functional models of gear transmissions are shown in Figure 1). These equations can be solved analytically, but due to the fact that there may be a large number of complex equations, various CAE programs are used. They can speed up finding a solution that ensures the minimization of vibroa-

a)

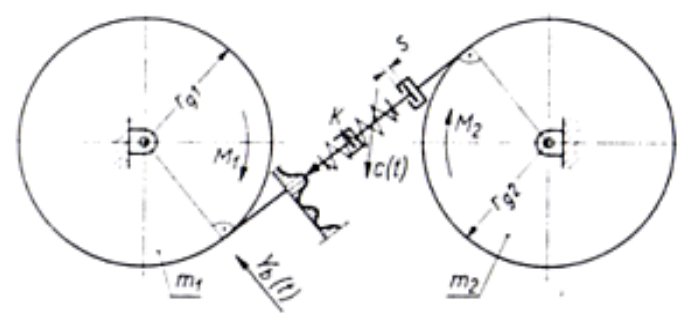

b)

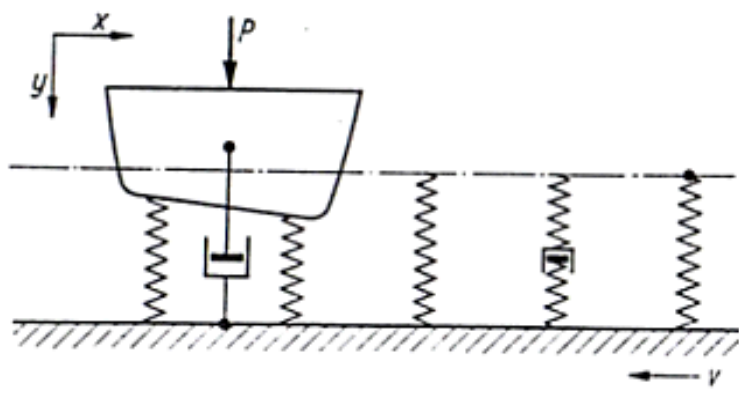

d)

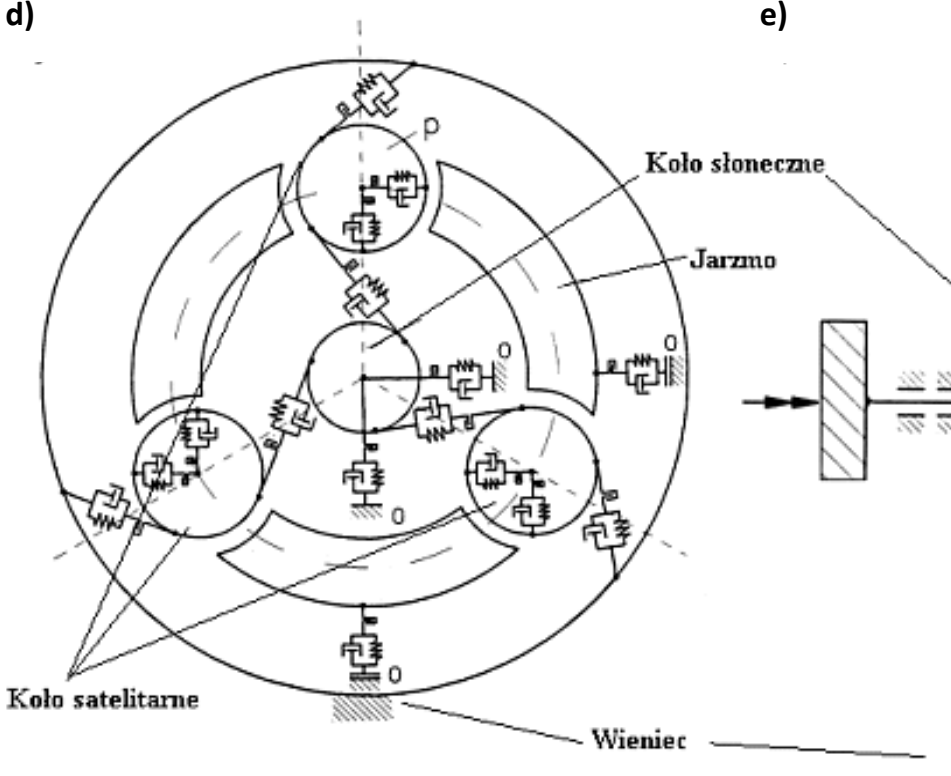

coustic effects. A correctly built model allows performing a thorough examination of mechanical and dynamic properties at a low cost, which allows preparing more design solutions, evaluating them, and then building the final solution. This advantage is particularly important for the industry because it offers an interesting tool for engineers.

Figure 2 shows a model of a single-stage gear transmission built with the use of programmable modules of the SimulationX software as well as the results of the simulation of gear wheel vibrations as a function of the time of operation obtained by the method of solving differential equations that describe the non-linear phenomena associated with the operation of gear wheels.

c)

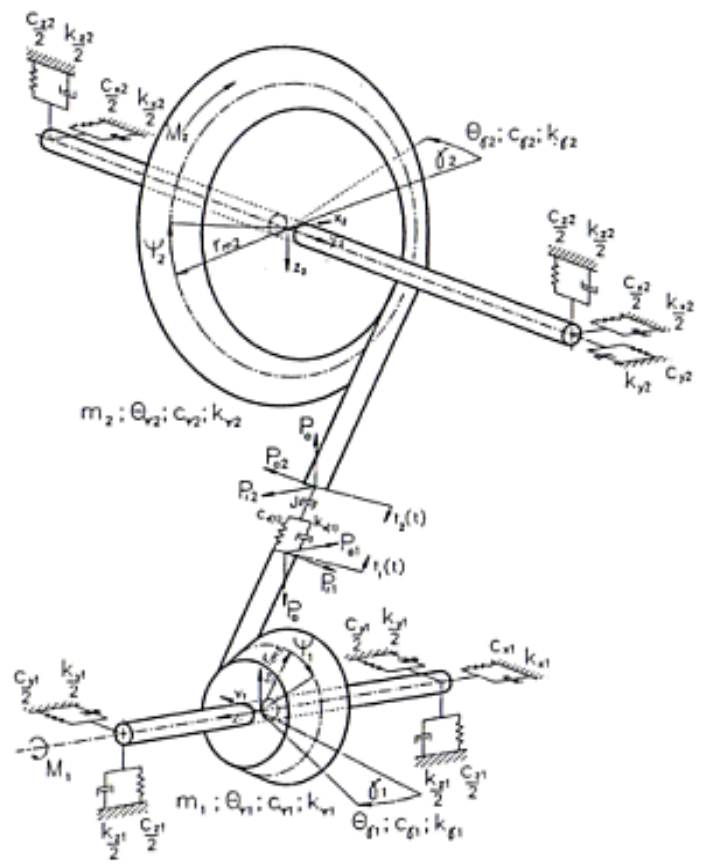

e)

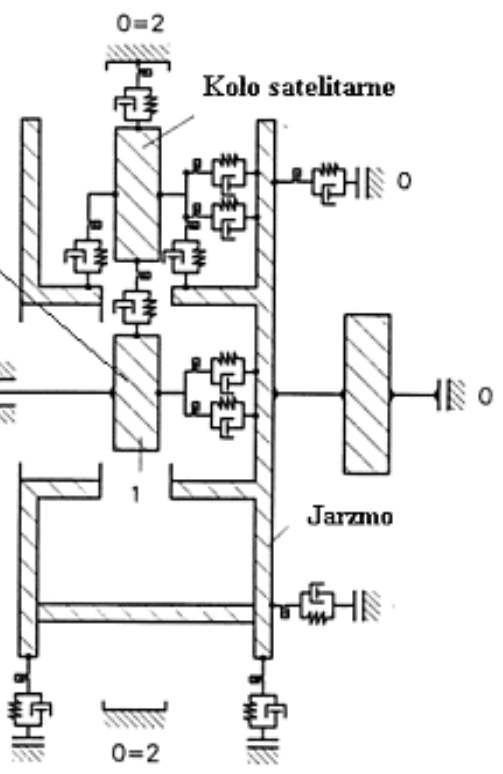

Fig. 1 Typical models of the gear transmissions:

a) Bosh's and Borlinger's model of a transmission gear [8], b) Müller's palisade model [9], c) model of a bevel gear transmission with many degrees of freedom [10], d) model of a planetary transmission - longitudinal section [11], e) model of a planetary transmission frontal section [11] 
a)

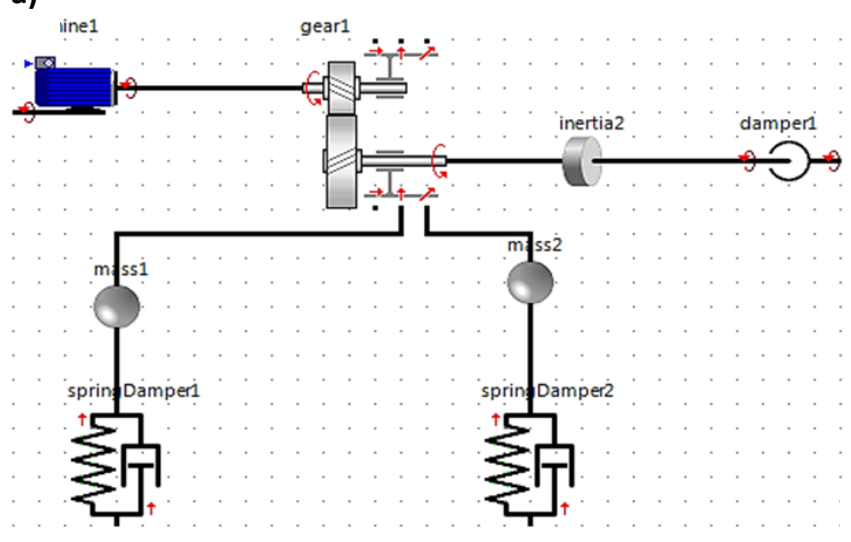

b)

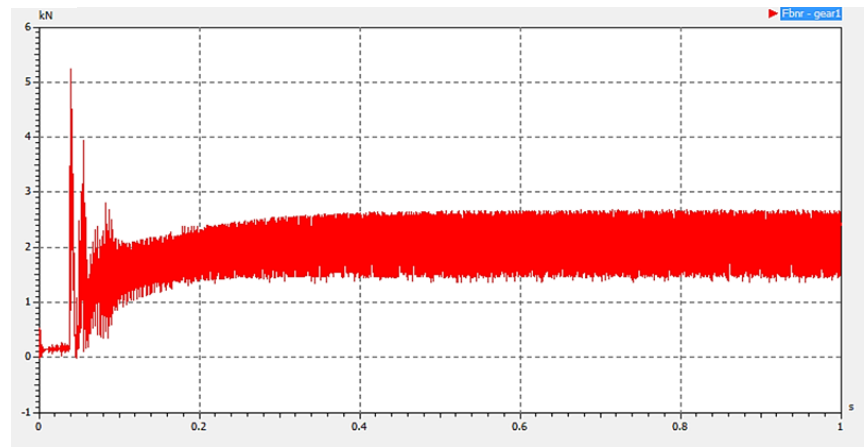

Fig. 2 Numerical investigations in the SimulationX environment: a) model of a single-stage gear transmission, b) example of results of the simulation of gear wheel vibrations as a function of time

The start-up phase can easily be noticed in the graphs of these vibrations. It is characterized by an initial increase in the value of torsional vibration accelerations.

In addition to analytical calculations, the basic calculation methods $[4,5]$ used in engineering calculation software include:

- finite element method,

- rigid finite element method,

- finite difference method,

- finite volume method,

- numerical integration method.

These methods consist principally in creating a solid element representing a real object, dividing the continuous area under consideration into a finite number of sub-areas (meshing), and then finding an approximate solution in the sub-areas.

Experimental studies on the vibroacoustic effects generated in gear transmissions can be divided into:

- studies on the impact of the selected parameters of gear wheels and lubricants conducted at mechanical closed-loop power test rigs (an example of such a test rig is shown in Fig. 3a) equipped with a system for measuring vibrations; this test rig is used to test replaceable gear wheels [12],

- operational or control tests carried out at electrical closed-loop power test rigs (these are generally systems consisting of motors and inverters, which enable return of power to the grid) equipped with systems that monitor for example the torque, mechanical vibrations and temperature; this test rig is used to test complete gear transmissions (an example of a gear transmission prepared for testing at the test rig is shown in Fig. 3b). a)

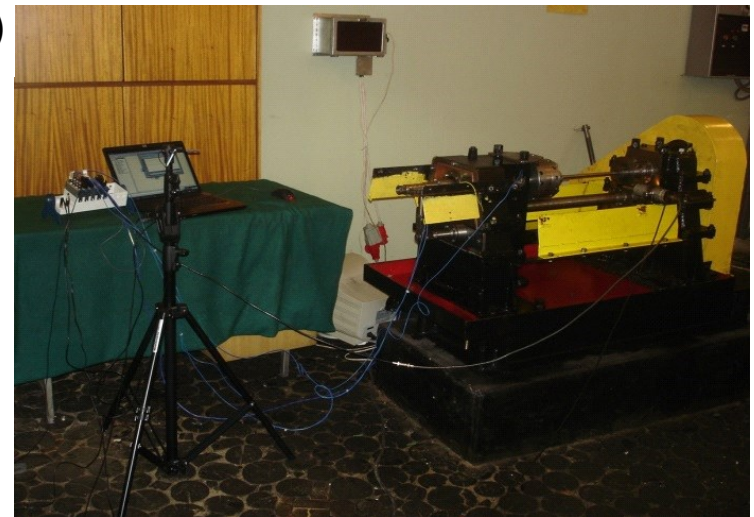

b)

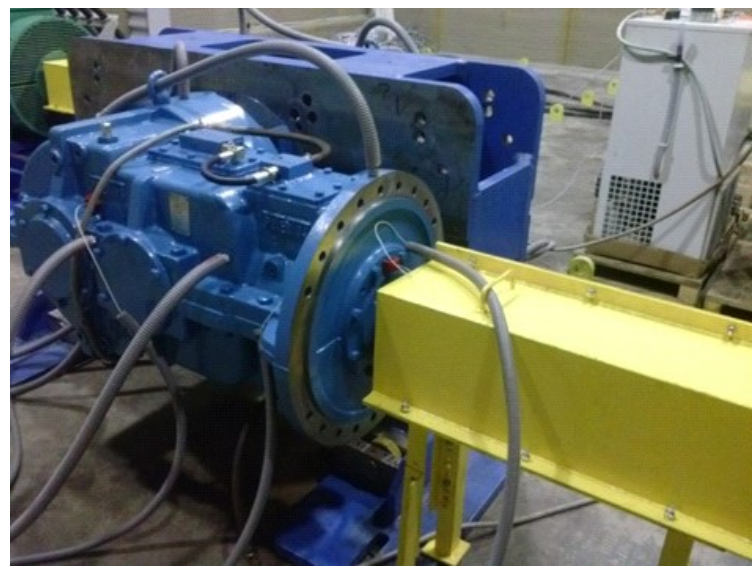

Fig. 3 Test rigs for tests of gear transmissions:

a) mechanical closed-loop power test rig, b) view of a gear transmission prepared for tests under a load on the electrical closed-loop power test rig

The hybrid methods that combine experimental and numerical studies are used very often, because the development of a verified model of a gear transmission allows obtaining the knowledge which takes many factors into account. Realization of a wide research programme that includes only experimental studies would be associated with huge costs and long time required for the measurements $[13,14,15,16]$.

\section{OPERATIONAL FACTORS CAUSING VIBRATIONS OF GEAR TRANSMISSIONS}

In the case of gear transmissions, gear wheels and bearings are particularly responsible for vibroacoustic conditions [17]. These are also elements that should meet high durability requirements, and this fact has a substantial influence on the economic aspect of the use of gearboxes. In the structure of failures of gear transmissions, damage to gear wheels has a significant share - up to approx. $40 \%$ [18].

The factors affecting the vibroacoustic conditions are divided [14] into external and internal ones. External excitations include changes in the load, unbalancing and assembly faults in the entire drive unit.

As regards internal factors, three main groups of factors [19] that affect the vibroacoustic conditions of gear transmissions are distinguished:

- design factors that include the nominal rotational speed, nominal meshing frequency, nominal load of the gear transmission, damping properties of the lubricant, bearing stiffness, design of the gear housing, and free vibrations of the system, 
- manufacturing factors that include pitch deviations, deviations of the pitch line direction, modification of the tooth profile and the pitch line direction, fit of bearings and their preload, precision of the assembly,

- factors disrupting the movement of gear transmissions, which include changes in the mesh stiffness and damping in the meshing at the section of the tooth contact, deformation of teeth caused by the load, dynamic unbalancing of wheels and shafts, excitations induced by friction, changes of mating conditions of gear wheels associated with the wear of tooth surfaces.

During the operation of gear transmissions, the impact of a number of operational factors on their vibroacoustic conditions is observed. Among those already mentioned, this group includes:

- variable load caused by operating conditions of machines - the impact of this factor generally can be reduced by the use of a suitable coupling connecting the machine with the transmission and by maintaining this coupling in a good technical condition,

- unbalancing and assembly faults in the entire drive unit - the impact of this factor often manifests itself during the operation of the machines; the impact of this factor can be reduced by controlling these parameters and possibly correcting the settings of individual components of the system,

- operation of transmissions in subharmonic conditions of the main resonance - the impact of this factor often manifests itself in the form of local increases of the parameters characterizing the vibrations; in the case of units with inverters it is possible to change the value of the rotational speed and thus the resonance conditions of the operation of the gear transmission,

- change in the mating conditions of gear wheels associated with the wear of tooth surfaces - the impact of this facto manifests itself in the progressive damage to the surface of gear wheels and bearings.

The operational factors may include also:

- the temperature of the lubricating oil - this factor often results from inadequately selected cooling conditions; the impact of this factor can be reduced by adding additional devices that increase the heat transfer from the gear transmission,

- reduced heat transfer from the gear transmission housing caused by a layer of pollutants - the impact of this factor can be reduced by cleaning the housing.

It can be easily noticed that the negative impact of these factors can be minimized through appropriate measures taken by company's maintenance services. The advantage achieved through these measures will consist in an increase in the service life of the machines and equipment (resulting from a reduction of the total load caused by the operating torque and dynamic surpluses), as well as in the improved working environment. The advantages mentioned here are extremely important due to the significance of the efficiency and safety of operation for the achievement of the assumed economic indicators by production companies.

\section{ANALYSIS OF THE IMPACT OF THE SELECTED OPERATIONAL FACTORS ON THE VIBROACOUSTIC EFFECTS GENERATED BY GEAR TRANSMISSIONS}

Among the already mentioned operational factors that affect the vibroactivity of gear transmissions, the following factors are particularly important due to the possibility of reducing the dynamic excitations by maintenance services: changes in the mating conditions of gear wheels associated with the wear of tooth surface, operation of transmissions in subharmonic conditions of the main resonance and the temperature of the lubricating oil. The following subsections outline the results of the studies related to the impact of those factors on the vibroacoustic emissions.

\section{Impact of the tooth surface wear}

Premature end of the service life of a gear transmission caused by damage to gear wheels may occur $[19,20]$, inter alia, as a result of fatigue pitting of the surface layer. When pitting occurs, it often happens in practice that the operation of the gear transmission is to be continued by the time of a planned major overhaul, but this is associated with a risk of teeth fractures initiated by pitting of the surface and thus a risk of a major failure. Pitting in gear transmissions (examples of gear wheels damaged by pitting are shown in Fig. 4) appears in the places which are in contact with the lubricant. Disturbance of the surface layer leads to the formation of a crack, in which the lubricant is accumulated. The crack filled with grease or oil becomes loaded (e.g. during meshing), which results in an increased pressure and in the expansion of the crack.

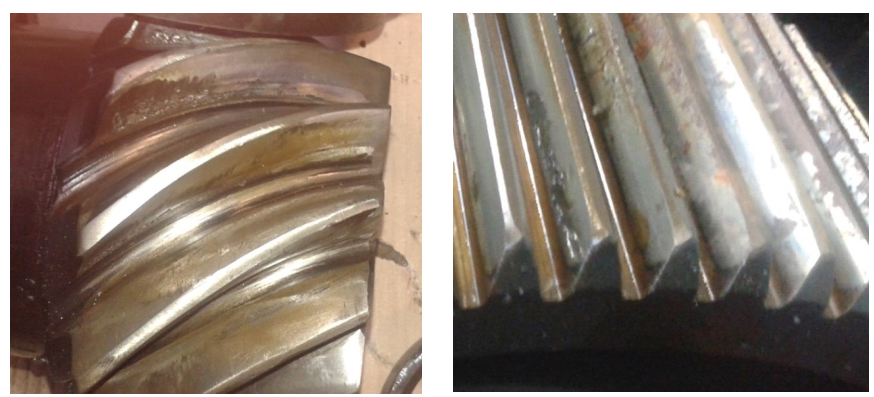

Fig. 4 Examples of gear wheels damaged by pitting

As a part of the experiment conducted with the use of the mechanical closed-loop power test rig (technical details are presented in [21]), gear wheels with various surface conditions were subjected to tests. On one surface of the test wheel (Fig. 5a), there were many signs of damage typical of the fatigue pitting of the surface layer (the surface damaged by pitting was $3.15 \pm 0.34 \%$ of the surface of the mating teeth), while the second surface was not damaged. a)

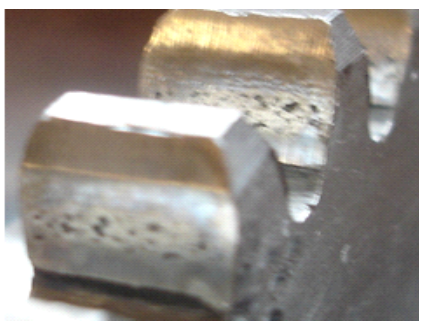

b)

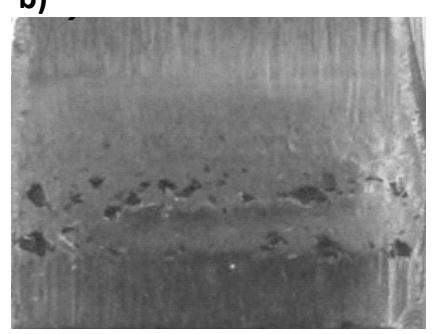

Fig. 5 View of surfaces of the gear wheels tested: a) general view of damaged tooth surfaces, b) magnified view of destroyed surface 


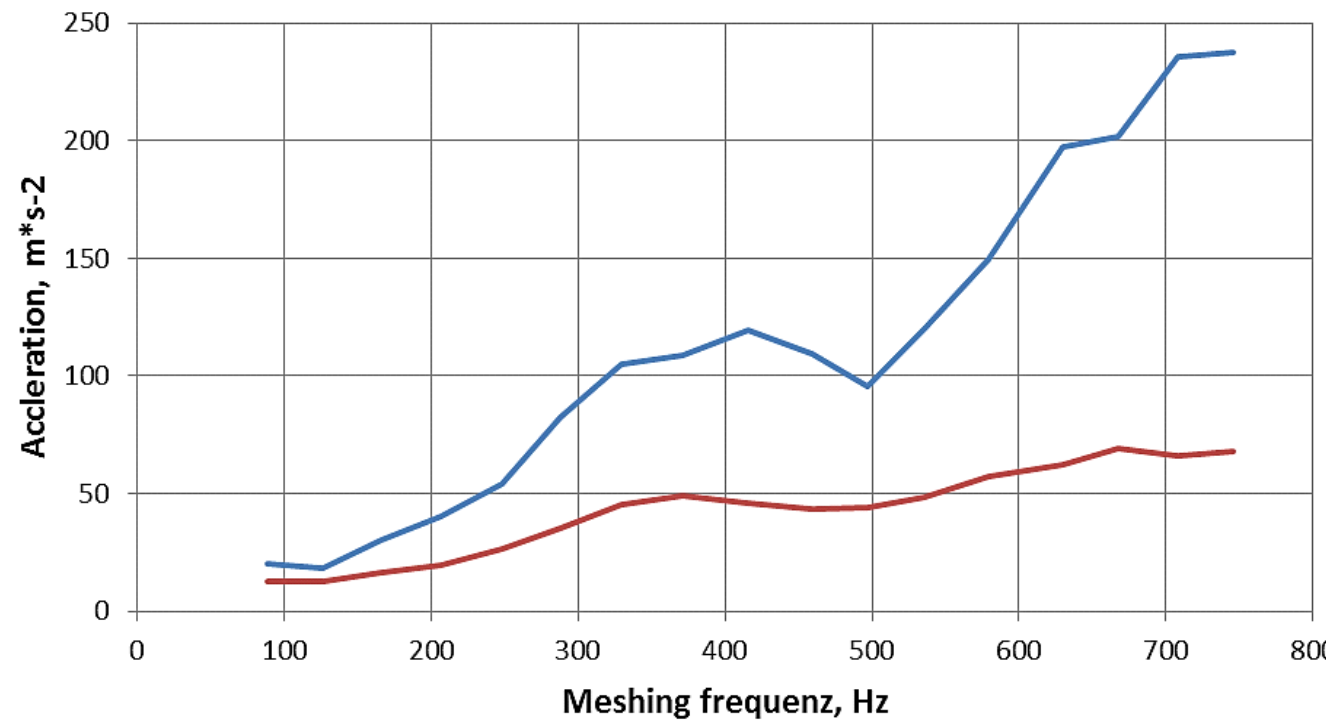

$\longrightarrow$ PITTING $\quad$ WITHOUT PITTING

Fig. 6 Graphs of the acceleration of vibrations of the gear transmission housing as a function of the rotational speed - for wheels with pitting and without it

Table 1

Summary of the determined values of the rotational speed and meshing frequency of the subharmonics of the main resonance, $n_{E}$-rotational speed of the main resonance, $f_{E}$ - meshing frequency of the main resonance

\begin{tabular}{ccccc}
\hline$\frac{n_{E}}{1}$ & $\frac{n_{E}}{2}$ & $\frac{n_{E}}{3}$ & $\frac{n_{E}}{4}$ & $\frac{n_{E}}{5}$ \\
7706 RPM & 3853 RPM & 2569 RPM & 1927 RPM & 1541 RPM \\
$\frac{f_{E}}{1}$ & $\frac{f_{E}}{2}$ & $\frac{f_{E}}{3}$ & $\frac{f_{E}}{4}$ & $\frac{f_{E}}{5}$ \\
$3339 \mathrm{~Hz}$ & $1670 \mathrm{~Hz}$ & $1113 \mathrm{~Hz}$ & $835 \mathrm{~Hz}$ & $668 \mathrm{~Hz}$ \\
\hline
\end{tabular}

The acceleration of vibrations of the gear transmission housing was measured with the use of acceleration sensors placed near the roller bearing of the pinion shaft of the closing gear transmission. Figure 6 presents the results as a function of the rotational speed. It can easily be noticed in this figure that the damage to the tooth surface contributed to a drastic increase in the value of the estimates.

Impact of the operation of transmissions in subharmonic conditions of the main resonance

Gear transmissions are classified as non-linear systems, while vibrations are of parametric character $[9,13,14]$. This results from the possibility of a loss of contact between meshing teeth (backlash), a non-linear change in the rigidity of one pair of teeth as a function of the position of the contact point at the section of tooth contact, a stepwise change in the mesh stiffness resulting from changes in the number of pairs of teeth in contact. In non-linear systems, in addition to the main resonance, there are also subresonances and super-resonances, which become apparent for the frequencies being a fraction $\mathrm{m} / \mathrm{n}$ of the frequency of the main resonance ( $m$ and $n$ - natural numbers).

In order to determine the impact of the resonance conditions on the vibroacoustic conditions of a gear transmission, the following values were determined on the basis of the methodology given in ISO-PN 6336:2007 standard [19]: average mesh stiffness of the test gear wheels ( $c=1,83 \cdot 108$ $\mathrm{N} / \mathrm{m}$ ), the rotational speed and mesh frequency correspon- ding to the main resonance of the test wheels and to individual subharmonics. The results of the calculations are presented in Table 1. The parameter to be measured was the acceleration of torsional vibrations of gear wheels (the manner of conducting the experiment with the use of a mechanical closed-loop power test rig was discussed in [22, $23,24])$. The results are shown in Figure 7.

For the meshing frequency values $\mathrm{fz}=800 \mathrm{~Hz}$ and $\mathrm{fz}=1150 \mathrm{~Hz}$, the local maxima of vibrations for the static torque load of $50 \mathrm{Nm}$ are observed. These values correspond approximately to the values of the 4 th and $3 \mathrm{rd}$ subharmonics of the main resonance (Table 1 ).

In the range $\mathrm{fz}=1050 \div 1200 \mathrm{~Hz}$, in which the value of the 3rd subharmonic of the main resonance is located, the difference between the maximum and minimum values of the vibration accelerations is significant (approx. $50 \mathrm{~m} \cdot \mathrm{s}-2$ ). By changing the rotational speed of the driving motor with the use of inverters, a significant improvement in vibroacoustic conditions of the gear transmission can be obtained. However it should be remembered that this is not always possible - for example when the assumed system performance is taken into account. Figure 7 shows also the impact of the load on the value of the rotational speed, at which local extremes of the vibration acceleration can be observed. The reason for this phenomenon is probably a change in the resultant mesh stiffness [19]. 
Figure 8 shows graphs of the vibration velocity of an industrial gear transmission (presented in Fig. 3B) as a function of the meshing frequency. In this case, like in Figure 7, the non-linear character of the vibration velocities as a function of the rotational speed become visible. In the range of rotational speeds $n=1100 \div 1200$ a significant increase in the vibration velocities is observed as compared with the vibrations outside this range.

\section{The impact of the temperature of the lubricating oil}

Increased heating of oil during the operation of gear transmissions is a fundamental design and operational problem [20]. An increase in the temperature of lubricating oil has an adverse impact on machines and technical equipment. Along with the increase in the temperature, a decrease in the oil viscosity takes place, which has a considerable impact on the thickness of the oil film and thereby on the wear properties. In the case of a significant increase in the oil temperature, there is also a possibility of oil leaks from seals, which may result in complete destruction of the teeth. A reduction in the viscosity of the lubricating oil is also associated with a decrease in damping of the forces generated by meshing, which results in an increase in the dynamic forces and thus in an increase in the load of gear transmission elements such as gear wheels and bearings.

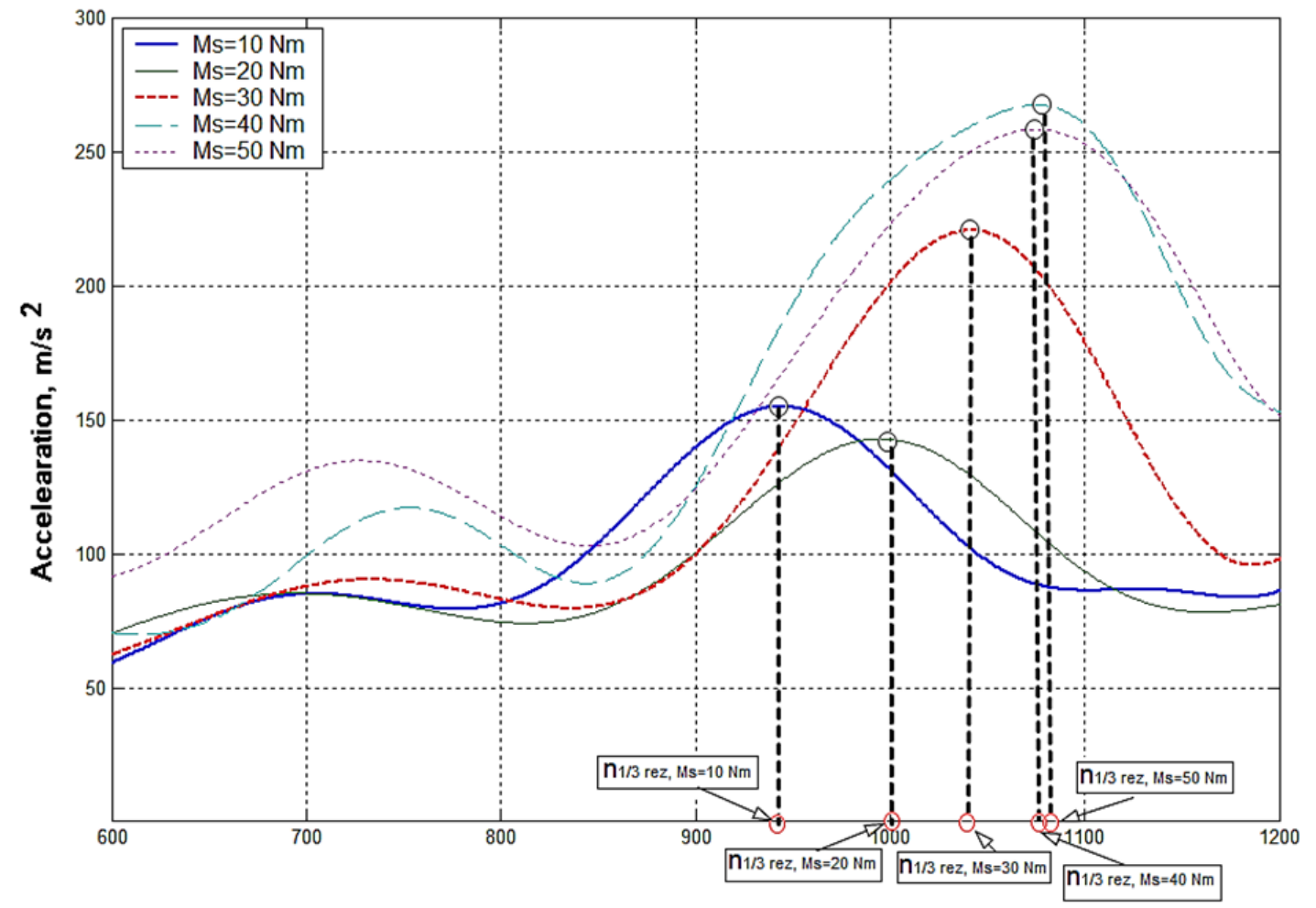

Meshing frequenz, $\mathrm{Hz}$

Fig. 7 Graphs of the accelerations of torsional vibrations of the test wheels as a function of the meshing frequency

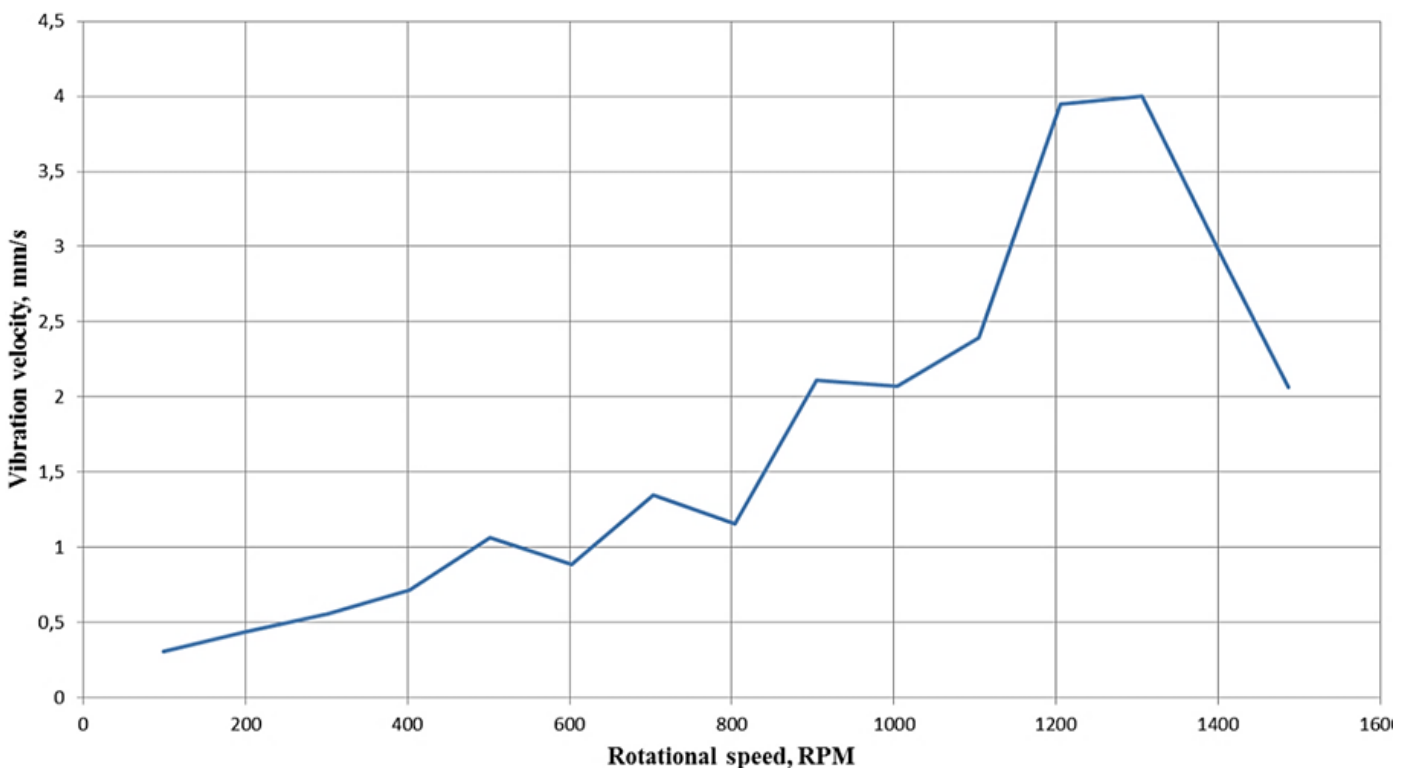

Fig. 8 Graphs of the vibration velocity of an industrial gear transmission as a function of the rotational speed 


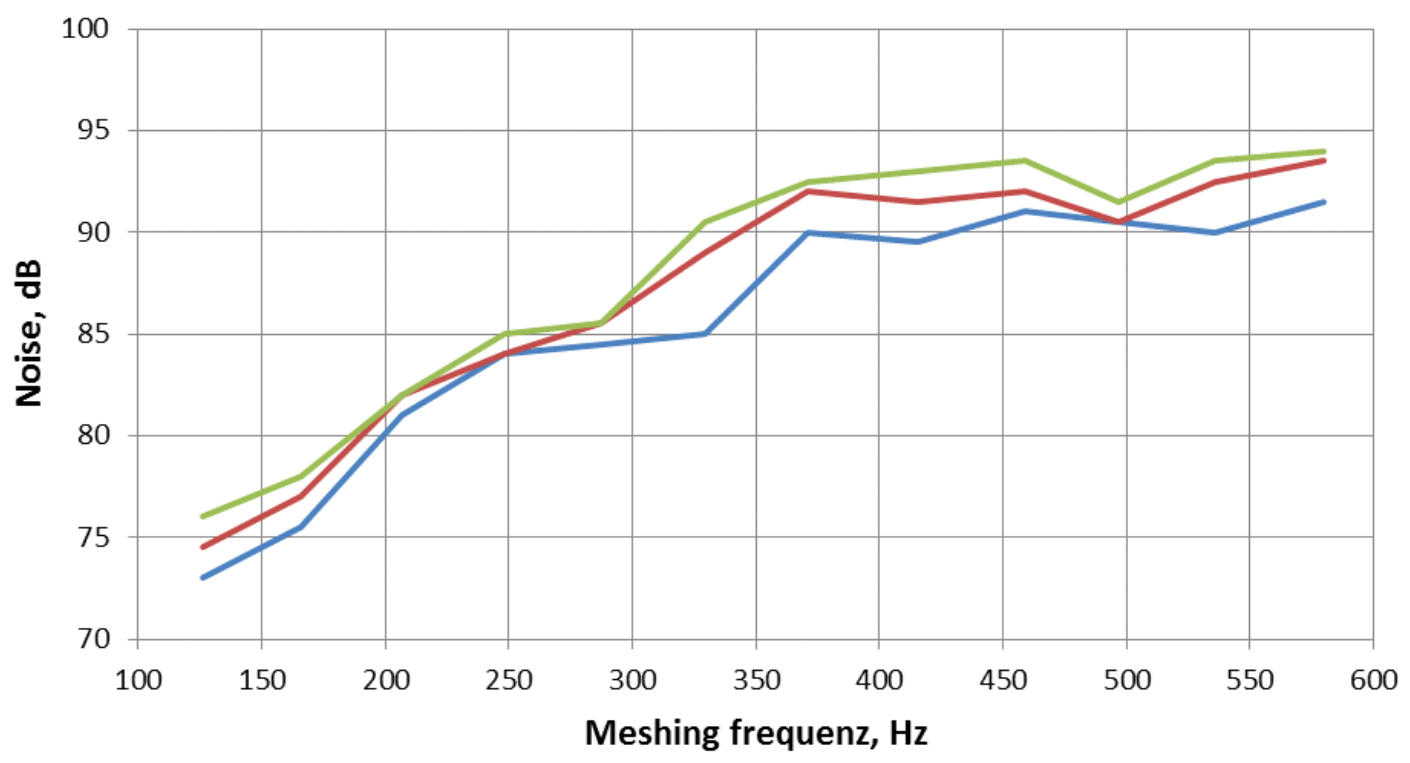

$-30^{\circ} \mathrm{C}-40^{\circ} \mathrm{C}-50^{\circ} \mathrm{C}$

Fig. 9 Graphs of the measured sound pressure level as a function of the temperature of the lubricating oil

Figure 9 shows values of the sound pressure levels measured for different temperatures of mineral lubricating oil with the viscosity grade of 320 , obtained under the experiment with the use of the mechanical closed-loop power test rig [25]. It can be seen in this figure that an increase in the oil temperature is associated with an increase in the measured values of the sound pressure level.

\section{SUMMARY}

In correctly functioning maintenance systems it is most important to prevent possible failures. Many companies pay attention to the vibroacoustic conditions only in the event of damage to the system components that may cause a major failure. Failures of technical equipment are often caused by an additional load generated by mechanical vibrations. In correctly functioning maintenance systems, ensuring adequate levels of vibration and noise should be treated as one of measures for preventing failures.

The paper presents the results of the research on the impact of operational factors on vibroacoustic conditions of transmissions. The factors covered by the analysis included a change in the mating conditions of gear wheels associated with the wear of tooth surfaces, operation of transmissions in subharmonic conditions of the main resonance and the temperature of the lubricating oil. The study demonstrated that it was possible to reduce the vibroacoustic effects generated by gear transmissions by changing the conditions of their operation. Maintenance departments in companies are capable of changing these conditions.

Based on the results obtained, it can be concluded that the operation of gear transmissions in accordance with the sustainable development principles requires technical services to take active measures consisting in the search for optimal operating conditions. One of the most important criteria for optimizing the operating conditions should be minimization of the vibroacoustic conditions of gear transmissions.

The study was carried out as a part of the project "Development of an innovative pro-ecological specialized gear transmission integrated with a diagnostic system" No. POIG.01.04.00-24-094/11.

\section{REFERENCES}

[1] A.N. Wieczorek. „Projektowanie maszyn i urządzeń zgodne z zasadą zrównoważonego rozwoju", in Management Systems in Production Engineering, vol. 1(17), May 2015, pp. 28-34.

[2] L. Kaźmierczak-Piwko. „Rozwój instrumentów zrównoważonego rozwoju sektora przedsiębiorstw", in Management Systems in Production Engineering, vol. 4(8), October 2012, pp. 37-39.

[3] V. Veleva, M. Hart, T. Greinerm and C. Crumbley. "Indicators of sustainable production", in Journal of Cleaner Production, vol. 9(5), October 2001, pp. 447452.

[4] M. Kmiotek. „Przegląd solverów numerycznych stosowanych w mechanice obliczeniowej”, in Scientific Bulletin of Chetm Section of Mathematics and Computer Science, vol. 1, 2008, pp. 151-158.

[5] D. Skibicki and K. Nowicki. Metody numeryczne w budowie maszyn, Bydgoszcz: Wydawnictwo Uczelniane Akademii Techniczno-Rolniczej, 2006.

[6] W. Kramarczuk, R. Kruk, A. Lohrengel, A. Wieczorek and K. Twardoch. „Modelowanie zjawisk dynamicznych w przekładniach zębatych z wykorzystaniem metody elementów sztywnych", in Górnictwo i Geologia, Tom VI, zeszyt 3, 2011, pp. 115-126.

[7] P. Dietz, R. Kruk, A. Lohrengel and A. Wieczorek. „Doświadczalne i obliczeniowe wyznaczanie parametrów dynamicznych łożysk tocznych", in Górnictwo i Geologia, Tom III, zeszyt 2, 2008, pp. 15-16.

[8] M. Bosch. Das dynamische Verhalten von Stirnradgetriebe unter besonderer Berücksichtigung der Verzahnungsgenauigkeit. Industrie-Anzeiger, Part 1: 102/1965.

[9] L. Müller. „Nowy model dynamiczny przekładni walcowej o zębach prostych", in Przeglad Mechaniczny, vol. 21, 1974, pp. 725-728.

[10] A. Skoć. Dynamika przekładni zębatych stożkowych maszyn górniczych. Zeszyty Naukowe Politechniki Ślqskiej (seria Górnictwo), vol. 226, no 1317, Gliwice 1996. 
[11] Ch. Lamparski. Einfache Berechnungsgleichungen für Lastüberhöhungen in Leichtbauplanetengetrieben. Schriftenreihe des Instituts für Konstruktionstechnik, Heft Nr. 95.3, Ruhr-Universität Bochum, Germany, 1995.

[12] L. Müller. Przekładnie zębate - Badania, Warszawa: WNT, 1984.

[13] B. Łazarz. Zidentyfikowany model dynamiczny przekładni zębatej jako podstawa projektowania. Monograficzna Seria Wydawnicza Biblioteka Problemów Eksploatacji - Studia i Rozprawy, Katowice - Radom 2001.

[14] Z. Dąbrowski, S. Radkowski and A. Wilk. Dynamika przekładni zębatych. Badania i symulacja w projektowaniu eksploatacyjnie zorientowanym, Radom: Wydawnictwo Naukowe ITE, 2000.

[15] W. Bartelmus. Diagnostyka Maszyn: Górnictwo Odkrywkowe, Katowice: Wydawnictwo Naukowe Śląsk, 1998.

[16] W. Bartelmus. Gearbox dynamic modeling, in Journal of Theoretical and Applied Mechanics, vol. 39(4), October 2001, pp. 989-999.

[17] L. Müller. Przekładnie zębate - Dynamika, Warszawa: WNT, 1986.

[18] K. Ehrlenspiel. „Betriebserfahrungen mit Stirnrad- und Planetengetrieben - Maßnahmen zur Schadenverhütung", in Der Maschineneschaden, vol. 45(4), May 1972, pp. 133-134.
[19] Norma PN-ISO 6336: 2007. Calculation of load capacity of spur and helical gears Part 1: Basic principles, introduction and general influence factors.

[20] K. Nadolny. Tribologia kół zębatych: zagadnienia trwałości i niezawodności, Poznań-Radom: Wydawnictwo Politechniki Poznańskiej - ITE, 1999.

[21] A. Wieczorek and A. Gola. „Wstępne badania wpływu stanu eksploatacyjnego na drgania przekładni zębatych", in Trwałość elementów i węzłów konstrukcyjnych maszyn górniczych (TEMAG 2010), October 2010, pp. 241-247.

[22] A. Wieczorek. Wpływ wysokości uzębienia kół na obciążenie dynamiczne przekładni. PhD thesis, Gliwice, Poland, 2007.

[23] A. Wieczorek. „The Effect of Construction Changes of the Teeth of a Gear Transmission on Acoustic Properties", in International Journal Of Occupational Safety, vol. 18(4), January 2015, pp. 499-507.

[24] A. Wieczorek. „Reducing the causes of mechanical vibrations of gear transmissions through construction changes in teeth", in Machine Dynamics Problems, vol. 34(4), December 2010, pp. 118-129.

[25] A. Wieczorek and R. Kudyba. „Wyniki badań wpływu temperatury oleju na poziom hałasu emitowany przez przekładnie zębate", in Trwałość elementów i węzłów konstrukcyjnych maszyn górniczych (TEMAG 2009), October 2009, pp. 249-254.

dr inż. Andrzej N. Wieczorek

Silesian University of Technology, Faculty of Mining and Geology

Institute of Mining Mechanization

ul. Akademicka 2A, 44-100 Gliwice, POLAND

e-mail: andrzej.n.wieczorek@polsl.pl

mgr inż. Radosław Kruk

TU Clausthal

Institut für Maschinenwesen, GERMANY

Artykuł w polskiej wersji językowej dostępny na stronie internetowej czasopisma.
The article in Polish language version available on the website of the journal 